\title{
Improvement of Cymbopogon flexuosus Biomass and Essential Oil Production With Organic Manures
}

\author{
Vauvenargues Lopes ${ }^{1}$, Suzan Kelly Vilela Bertolucci ${ }^{1}$, Alexandre Alves de Carvalho', \\ Heitor Luiz Heiderich Roza ${ }^{1}$, Felipe Campos Figueiredo ${ }^{2}$ \& José Eduardo Brasil Pereira Pinto ${ }^{1}$ \\ ${ }^{1}$ Laboratory of Plant Tissue Culture and Medicinal Plants, Department of Agriculture, Federal University of \\ Lavras, Lavras, Brazil \\ ${ }^{2}$ Laboratory of fertilizer, Department of Soil Science, Federal Institute of Minas Gerais South, Muzambinho, \\ Brazil \\ Correspondence: José Eduardo Brasil Pereira Pinto, Laboratório de Cultura de Tecidos e Plantas Medicinais, \\ Departamento de Agricultura, Universidade Federal de Lavras, Câmpus Universitário, Caixa Postal 3037, CEP \\ 37200-000, Lavras, Brazil. E-mail: jeduardo@dag.ufla.br
}

Received: October 10, 2018

Accepted: November 8, 2018 Online Published: January 15, 2019

doi:10.5539/jas.v11n2p169

URL: https://doi.org/10.5539/jas.v11n2p169

\begin{abstract}
Cymbopogon flexuosus is a medicinal species with relevant commercial value and widely used in flavors, fragrances, toiletries, cosmetics, soaps, detergents, and pharmaceutical products. The objective of this study was evaluate the effects of different doses and sources of two manures and one compost on plant growth, leaf nutrient accumulation, content, yield, and chemical composition of the essential oil. The sources were cattle manure, quail manure, and organic compost applied in four doses and control treatment. The species increased the growth and productions of secondary metabolites by use the manures and organic compost. The highest weight gain was obtained with fertilization between 300 and $450 \mathrm{~g} \mathrm{pot}^{-1}$ of quail manure, but the yield of essential oil in the doses from 150 to $300 \mathrm{~g} \mathrm{pot}^{-1}$. Overall, lemon grass plants fertilized with quail manure accumulated greater concentrations of nutrients in leaf tissue than cattle manure and compost. The neral content in the essential oil was increased with the use of quail manure compared to compost and cattle manure. The results from this study demonstrated that dose and source can alter dry weight, leaf nutrients accumulation, and essential oil content and yield.
\end{abstract}

Keywords: cattle manure, citral, medicinal plant, organic compost, quail manure

\section{Introduction}

Cymbopogon flexuosus (Nees ex Steud) J. F. Watson is commonly known as East Indian lemon grass, Cochin grass, and Malabar grass, being a medicinal species from South Asia, Southeast Asia, and Australia (May et al., 2008; Marigowda et al., 2016). China and Indonesia are the main producing countries of C. flexuosus essential oil, however, significant plant yields also occur in Guatemala. With relevant commercial value and more productive than Cymbopogon citratus, the species is used in flavors, fragrances, toiletries, cosmetics, soaps, detergents, and pharmaceutical products (May et al., 2008; Ganjewala \& Luthra, 2010).

Lemon grass essential oil was reported to have sedative, digestive, antirheumatic, soothing, antifebrile, carminative, analgesic, antispasmodic, and antimicrobial activities (May et al., 2008; Meena et al., 2016). Cytotoxic and anticancer potentials were reported by Marigowda et al. (2016) and by Sharma et al. (2009), thus being a good candidate for innovative therapeutic strategies against cancer. The oil consists mainly of citral, formed by the racemic mixture of geranial and neral (Gupta \& Ganjewala, 2015). The insecticidal and larvicidal against Aedes aegypti (Vera et al., 2014), antifungal (Ganjewala \& Luthra, 2010), bactericidal and antimicrobial activities are attributed to citral (Adukwu et al., 2016). According to Marigowda et al. (2016), the continuous supply of essential oil and the increase of more productive cultivars are the priority in order to meet the growing demand of C. flexuosus.

The biomass production and the synthesis of active principles in medicinal plants depends on several factors, including genetic, climate, edaphic conditions, and cultural management ones (Rosal et al., 2011). The study of mineral nutrition of plants is essential, because the mineral nutrients are fundamental for the growth and 
development of plants, besides the production of secondary metabolites (Garlet \& Santos, 2008). According to Rosal et al. (2011), quantitative and qualitative variations may occur in the biosynthesis of secondary metabolites as a response to the application of agronomic techniques. According to these authors, studies involving fertilization in essential oil-producing species do not only aim at the production of biomass, but also seek to clarify the influence of these inputs in the yield and in the chemical composition of the oil. The practice of organic fertilization, besides providing nutrients to the plants, improves the physical soil structure, increases water retention, reduces erosion losses, and favors biological control (Costa et al., 2008).

In this respect, studies regarding the effect of manures on biomass gain and essential oil biosynthesis have been performed with several medicinal species, such as: Aloysia triphylla (Brant et al., 2010); Mentha arvensis (Chagas et al., 2011); Plectranthus neochilus (Rosal et al., 2011); Ocimum selloi (Costa et al., 2008); Ocimum basilicum (Bufalo et al., 2015); Hyptis suaveolens (Maia et al., 2008); Mentha piperita (Costa et al., 2008), Origanum vulgare (Corrêa et al., 2010), and Lippia alba (Marques et al., 2018). The use of manures and organic compost in medicinal plants justify by low costs and ambient sustainability compared to chemical fertilizers. Beside improves physical and chemical propriety of soil by enhancement of organic matters. The cultivation of medicinal plants with quail manure is justified due to the high levels of $\mathrm{N}^{-\mathrm{NH}_{4}}{ }^{+}$being an immediate and readily available source of $\mathrm{N}$ for the plants. Therefore, in the present work the principle objective was evaluate the effects of different doses and sources of two manures and one organic compost on plant growth, leaf nutrient accumulation, content, yield, and chemical composition of the essential oil of $C$. flexuosus.

\section{Material and Methods}

\subsection{Installation of the Experiment and Preparation of Scion}

The experiment was installed in the greenhouse of the Laboratory of Plant Tissue Culture and Medicinal Plants of the Department of Agriculture/Federal University of Lavras (DAG/UFLA), located in the southern region of Minas Gerais, Brazil, $21^{\circ} 14^{\prime} \mathrm{S}$ and $45^{\circ} 00^{\prime} \mathrm{W}$, and $918 \mathrm{~m}$ altitude. Mother plant of $C$. flexuosus belonging to the Medicinal Herb Garden of UFLA were identified and compared to the aromatic deposited by the IAC Herbarium, maintained by the number 45335 . The scions were propagated by clump division, with each tiller of $7 \mathrm{~cm}$ height approximately. It were cultivated in 128-cell styrofoam seedling trays containing the commercial substrate Plantmax $\mathrm{HT}^{\circledR}$ and kept in a greenhouse with $60 \%$ shading until they reached about $12 \mathrm{~cm}$ in height. The scions were transplanted to $10 \mathrm{~L}$ plastic pots containing soil plus treatments. Irrigation was performed three times a week in order to maintain the soil with field capacity moisture.

The experimental design was completely randomized in a factorial design $(3 \times 4+1)$ with four replications. The treatments were: two sources of manure (cattle and quail) and one compost applied in four doses $(150,300,450$,

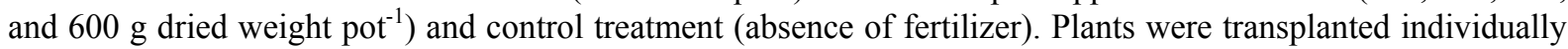
into the pots and each replicate was represented by five plants. The experiment was performed twice in greenhouse. Manures were collected on farms located in the municipality near the experiment. The decomposed manure was obtained from the natural process of decomposition during 120 days. The organic compost consisted of the mixture of quail manure and previously composted refrigerator wastes. The soil was the Dystrophic Red-Yellow Latosol (DRYL), collected in the city of Lavras/MG, Brazil, at 0-20 cm depth. Soil analyses were performed at the Laboratory of Chemical and Physical Soil Analysis of the Department of Soil Science of UFLA. Manures and compost analyses were performed in the laboratory of chemical analyses of the Regional Cooperative of Coffee Growers in Guaxupé Ltda (Cooxupé). The chemical and physical analyses of soil samples and fertilizers were performed according to the methodology proposed by EMBRAPA (1997) e Silva (2009), respectively.

The soil contained the following chemical fertility properties: $\mathrm{pH}$ in water $=5.6 ; \mathrm{P}$ and $\mathrm{K}\left(\mathrm{mg} \mathrm{dm}^{-3}\right)=0.6$ and 14; $\mathrm{Ca}^{2+}, \mathrm{Mg}^{2+}, \mathrm{Al}^{3+} \mathrm{H}+\mathrm{Al}\left(\mathrm{cmolc} \mathrm{dm}^{-3}\right)=0.5 ; 0.1 ; 0.0 ; 2.1$; base saturation $\mathrm{V}(\%)=23.4$; organic matter $\left(\mathrm{dag} \mathrm{kg}^{-1}\right)$ $=1.4$. The substrates used as fertilizers were also analyzed and generated the following values: a) cattle manure: $\mathrm{pH}$ in water $=8.2 ; \mathrm{N}, \mathrm{P}, \mathrm{K}, \mathrm{Ca}, \mathrm{Mg}, \mathrm{S}\left(\mathrm{g} \mathrm{kg}^{-1}\right)=18 ; 5.1 ; 13 ; 4.1 ; 3.2 ; 2.6$; and $\mathrm{B}, \mathrm{Cu}, \mathrm{Fe}, \mathrm{Mn}, \mathrm{Zn}\left(\mathrm{mg} \mathrm{kg}^{-1}\right)=5.6$; $39 ; 128 ; 461 ; 150$; b) Quail manure: $\mathrm{pH}$ in water $=7.4 ; \mathrm{N}, \mathrm{P}, \mathrm{K}, \mathrm{Ca}, \mathrm{Mg}, \mathrm{S}\left(\mathrm{g} \mathrm{kg}^{-1}\right)=26 ; 17.9 ; 40.5 ; 57.2 ; 7.8$; $7.2 ; \mathrm{B}, \mathrm{Cu}, \mathrm{Fe}, \mathrm{Mn}, \mathrm{Zn}\left(\mathrm{mg} \mathrm{kg}^{-1}\right)=66 ; 71 ; 811 ; 515 ; 680$; and c) organic compost: $\mathrm{pH}$ in water $=7.3 ; \mathrm{N}, \mathrm{P}, \mathrm{K}, \mathrm{Ca}$, $\mathrm{Mg}, \mathrm{S}\left(\mathrm{g} \mathrm{kg}^{-1}\right)=7.4,5.1 ; 5.5 ; 41 ; 2 ; 1.4 ; \mathrm{B}, \mathrm{Cu}, \mathrm{Fe}, \mathrm{Mn}, \mathrm{Zn}\left(\mathrm{mg} \mathrm{kg}^{-1}\right)=46 ; 27 ; 811 ; 204 ; 112$.

The first harvest occurred after 120 days of cultivation and the plant were cut above soil surface $(10 \mathrm{~cm})$. After 240 days of cultivation, the plants were harvested again $\left(2^{\text {nd }}\right.$ cut $)$ and separated in shoot and root. They were dried in a convection oven at $36 \pm 2{ }^{\circ} \mathrm{C}$ for three days. Root (RDW) and shoot dry weights of the $1^{\text {st }}$ (SDW1) and $2^{\text {nd }}$ cut (SDW2) were measured in grams per plant, using a precision scale. The total shoot dry weight (TSDW) represents the sum of shoot dry weights of the first and second cut (SDW1+SDW2) and the total dry weight 
(TDW) represents the sum of the shoot dry weight and root dry weight (TSDW+RDW). The root and shoot ratio (R:S) was obtained by dividing root dry weight by total shoot dry weight (RDW/TSDW).

\subsection{Leaf Tissue Analysis}

The samples collected for dry weight evaluation were ground in a Thomas Wiley mill and sent to the Laboratory of Leaf Analysis of the Department of Chemistry of UFLA in order to determine the contents of N, P, K, Ca, Mg, $\mathrm{S}, \mathrm{B}, \mathrm{Cu}, \mathrm{Mn}, \mathrm{Zn}$, and Fe according to methodology proposed by Malavolta et al. (1997).

\subsection{Extraction and Chemical Analysis of Essential Oil}

The essential oil extraction from C. flexuosus was performed by the hydro distillation process in a modified Clevenger apparatus using a sample of $100 \mathrm{~g}$ of dry leaf biomass in $1 \mathrm{~L}$ of distilled water for $90 \mathrm{~min}$. The essential oil was purified by liquid-liquid extraction with dichloromethane $(3 \times 5 \mathrm{~mL})$. The organic phase was combined and treated with about $5 \mathrm{~g}$ of anhydrous magnesium sulfate for $30 \mathrm{~min}$. Afterwards, the solution was filtered and the solvent evaporated at room temperature under an exhaust hood. Five replicates were obtained by essential oil treatment from samples composed of dry biomass, which were stored in amber flasks. Thereby, the content (\%) and the yield $\left(\mathrm{mg} \mathrm{plant}^{-1}\right)$ of the essential oil were determined.

Analyses of the chemical composition were performed based on a sample composed of equivolumetric aliquots of the essential oil of the replicates from each treatment. Quantitative oil analyses were performed by gas chromatography with flame ionization detector (CG-FID) on an Agilent ${ }^{\mathbb{B}} 7890 \mathrm{~A}$ system equipped with HP-5 fused silica capillary column ( $30 \mathrm{~m}$ length, $0.25 \mathrm{~mm}$ inner diameter and $0.25 \mu \mathrm{m}$ film thickness) (California, USA). Helium gas was used as carrier gas with flow of $1.0 \mathrm{~mL} / \mathrm{min}$; the injector and detector temperatures were maintained at $220^{\circ} \mathrm{C}$ and $240{ }^{\circ} \mathrm{C}$, respectively. The initial oven temperature was $60{ }^{\circ} \mathrm{C}$, isothermal for $1.5 \mathrm{~min}$, followed by a temperature ramp of $3{ }^{\circ} \mathrm{C} / \mathrm{min}$ up to $240{ }^{\circ} \mathrm{C}$, followed by a ramp of $10{ }^{\circ} \mathrm{C} / \mathrm{min}$ up to $270{ }^{\circ} \mathrm{C}$. The oil was diluted in ethyl acetate $(1 \%, \mathrm{v} / \mathrm{v})$ and injected automatically into the chromatograph using an injection volume of $1.0 \mu \mathrm{L}$ in split mode at 1:50 injection ratio. The quantitative analysis was obtained by integrating the total ion chromatogram (TIC) and the content of eluted constituents expressed as percent area relative to peak areas.

The qualitative oil analyses were performed by gas chromatography-mass spectrometry (GC-MS), using Agilent ${ }^{\circledR} 5975 \mathrm{C}$ equipment, operated by electron impact ionization at $70 \mathrm{eV}$, in scan mode, at a speed of 1,0 $\mathrm{scan} / \mathrm{s}$, with a mass acquisition interval of 40-400 $\mathrm{m} / \mathrm{z}$. The chromatographic conditions were the same as those used in quantitative analyses. The components were identified by comparing their calculated retention indices (IKc) with data from mass spectra and retention indices (IK) of literatures (Davies, 1990; Adams, 2007) and by comparing the mass spectra with the NIST/EPA/NHI library database (NIST, 2008). The Kovats retention indexes (IKc) relative to the co-injection of n-alkane pattern, C8-C20 (Sigma Chemical Co., St. Louis, MO, USA) were calculated with the application of the Van Den Dool and Kratz equation (1963).2.3.1 Sample Size, Power, and Precision

Along with the description of subjects, give the mended size of the sample and number of individuals meant to be in each condition if separate conditions were used. State whether the achieved sample differed in known ways from the target population. Conclusions and interpretations should not go beyond what the sample would warrant.

\subsection{Statistical Analysis}

The Statistica ${ }^{\circledR}$ software, version 13.3 (StatSoft-Tulsa, USA) was used for the statistical analyses of the experimental data. The observed values were submitted to analysis of variance (ANOVA, $p<0.05$ ). Regression analysis was used for data from dry weight and R:S. The average values of essential oil contents and yields were compared by Duncan'test $(\mathrm{p}<0.05)$. Principal component analysis (PCA) was used to study the major compounds of essential oil in relation to sources and doses of manures and compost.

\section{Results and Discussion}

Growth indicators were used to evaluate if source and dose influenced plant development and essential oil composition. The results obtained showed that there was an influence by source and dose used. A significance for the interaction between sources and doses of the manures and compost on dry weights and R:S was observed in the analysis of variance. Response curves were fitted by regression analysis for these variables (Figures 1a-1f). Quail manure doses increased, with quadratic effect, all dry weights (Figures 1a-1e). The superiority of the representative curve of quail manure in relation to other treatments was also observed. Therefore, it can observe that quail manure was more efficient to the other studied fertilizers and that the maximum yield of dried weight was obtained in specific doses. The doses $321.43,395.83,316.67,400$, and $337.50 \mathrm{~g} \mathrm{pot}^{-1}$ of quail manure 
provided the highest average weights $27.84,25.54,50.20,38.66$, and $88.34 \mathrm{~g} \mathrm{plant}^{-1}$ for SDW1, SDW2, TSDW, RDW, and TDW, respectively. Manure from intensive poultry farming, in which animals are fed with feed, is rich in nutrients, especially nitrogen and phosphorus, but poor in cellulose and lignin (Rosal et al., 2011). Considering TSDW as the main source of essential oil of this culture and that the dose of $300 \mathrm{~g} \mathrm{pot}^{-1}$ equaled to its maximum yield, the following amount of nutrients could be proposed (Table 1).

On the other hand, as observed in the quadratic trend of the curves, high doses of quail manure negatively influenced the biomass yield. Manures provide a diversity of ions in the soil solution, so that the presence of one can modify the absorption of another through synergistic and inhibitory interactions. According to Paula et al. (2015), the $\mathrm{K}$ absorption is inhibited competitively when the $\mathrm{Mg}$ concentration is high. Non-competitive inhibition is reported for $\mathrm{H}_{3} \mathrm{BO}_{3}$ in the presence of $\mathrm{NO}_{3}{ }^{-}$and $\mathrm{NH}_{4}{ }^{+}$(Marschner, 2012).
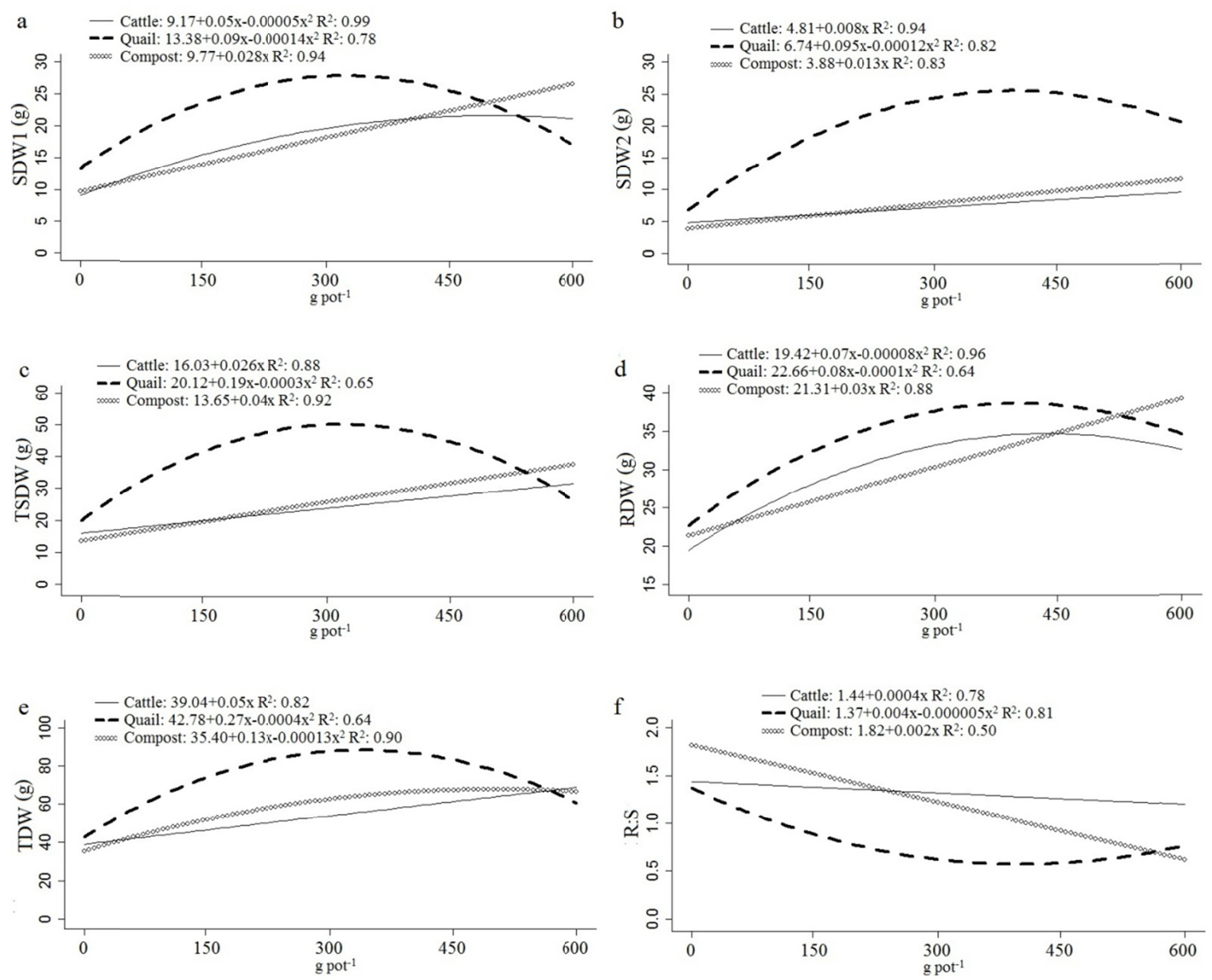

Figure 1. Effect of different sources and doses of manures and compost on: a) shoot dry weight in the first cut (SDW1), b) shoot dry weight in the second cut (SDW2), c) total shoot dry weight (TSDW), d) root dry weight $(\mathrm{RDW}), \mathrm{e})$ total dry weight (TDW) and f) root and shoot ratio (R:S) of C. flexuosos

In relation to cattle manure, SDW2, TSDW, and TDW were increased linearly in increasing doses (Figures $1 \mathrm{~b}$, $1 \mathrm{c}$, and 1e). The highest averages of SDW1 $(21.67 \mathrm{~g})$ and RDW (34.73 g) were observed at doses 500 and $437.50 \mathrm{~g} \mathrm{pot}^{-1}$ of cattle manure (Figures 1a and 1d). At the dose of $500 \mathrm{~g} \mathrm{pot}^{-1}$ of the organic compost, the maximum total dry weight (Figure 1e) was $67.90 \mathrm{~g}$ and the other dry weights linearly increased with increasing compost doses. Regarding the R:S ratio, in the different manures sources and compost, the highest values were obtained in the treatment without fertilization (Figure 1f). A decrease in this index is verified with the use of 400 $\mathrm{g} \mathrm{pot}^{-1}$ of quail manure $(0.57), 600 \mathrm{~g} \mathrm{pot}^{-1}$ of organic compost $(0.62)$, and cattle manure (1.20). This result indicated that the source of treatments with more nutrients directed the biomass distribution to the shoot of plant. 
Rosal et al. (2011) studied the effect of manures on the cultivation of Plectranthus neochilus and observed that the higher contribution of nutrient content, provided by fertilization with poultry manure, increased the shoot of plants, which stood out from the root dry weight. Still according to these researchers, the results evidenced a strong drainage from the shoot to the root, inasmuch as the fertilizer showed lower content of nutrients. This fact may be related to a survival mechanism developed by the plants, with greater investment in the root system, considering the greater soil exploration due to the low levels of nutrients in the growing environment. The effect of the manure doses on the increase of biomass yield has already been recorded for Ocimum selloi (Costa et al. 2008) and Capsicum chinense (Silva et al., 2018), being attributed to the increasing availability of nutrients. The results from study with sweet basil demonstrated that organic or conventional fertilizer altered fresh or dry weight (Bufalo et al., 2015). In contrast, the doses of organic fertilizers and minerals did not influence the biomass yield of the plant in Justicia pectoralis (Bezerra et al., 2006). Therefore, the possibilities of contradictory results are significant; thus, research relating sources and doses of manures sufficient to guarantee high yields with economic viability should be performed for each genotype.

Table 1. Quantity of nutrients in $\mathrm{g}$ per $10 \mathrm{~L}$ pot and $\mathrm{kg} \mathrm{ha}^{-1}$, considering a population of 20,000 plants ha ${ }^{-1}$ supplied by quail manure at the best tested dose $\left(300 \mathrm{~g} \mathrm{pot}^{-1}\right)$

\begin{tabular}{|c|c|c|c|c|c|c|c|c|c|c|}
\hline $\mathrm{N}$ & $\mathrm{P}$ & $\mathrm{K}$ & $\mathrm{Ca}$ & $\mathrm{Mg}$ & $\mathrm{S}$ & B & $\mathrm{Cu}$ & $\mathrm{Fe}$ & $\mathrm{Mn}$ & $\mathrm{Zn}$ \\
\hline ------ & - & - & $0 \mathrm{t}^{-1}-\cdots$ & ----- & 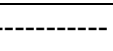 & - & -י----י & $-\mathrm{mg}$ pot & -1 & \\
\hline 7.80 & 5.37 & 12.15 & 17.16 & 2.34 & 2.16 & 19.80 & 21.30 & 243.30 & 154.50 & 207 \\
\hline ----. & $\cdots$ & - & $a^{-1}-\cdots$ & --- & & ---- & & $\mathrm{g} \mathrm{ha}^{-1}$ & 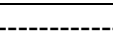 & \\
\hline 156 & 107 & 243 & 343 & 47 & 43 & 396 & 426 & 4866 & 3090 & 4140 \\
\hline
\end{tabular}

At the dose of $300 \mathrm{~g} \mathrm{pot}^{-1}$ of treatments, it was observed that the use of quail, cattle manure, and compost resulted respectively in 50.12, 23.83, and $25.65 \mathrm{~g}$ of shoot dry weight in both cuts. Thereby, quail manure was approximately $95 \%$ higher than cattle and $68 \%$ compared to the organic compost. It was also worth noting that, at this same dose, the gain of shoot weight was stable with use of quail manure between the cuts, averaging $28 \mathrm{~g}$ in the $1^{\text {st }}$ cut and $24 \mathrm{~g}$ in the $2^{\text {nd }}$ cut. However, for cattle manure and organic compost, the average of both was 20 $\mathrm{g}$ for the $1^{\text {st }}$ cut and $9 \mathrm{~g}$ for the $2^{\text {nd }}$ cut, resulted in a reduction of $45 \%$ in the dry weight of regrowth leaves. Comparison between the chemical compositions of manure may possibly clarify for the increase in dry weight yield provided by different manure sources. It was observed that quail manure had a higher concentration of macronutrients $(\mathrm{N}, \mathrm{P}, \mathrm{K}, \mathrm{Ca}, \mathrm{Mg}$, and $\mathrm{S})$ compared to other fertilizers. The nitrogen concentration in quail manure was 1.44 higher in relation to cattle manure and 3.51 higher in relation to the organic compost. This nutrient is related to the synthesis of structural compounds, such as proteins (Marschner, 2012).

Phosphorus directly controls the response of photosynthesis, plays a key role in the formation of high energy bonds and phospholipid membrane, and is an integral component of several metabolic reactions and signal transduction pathways (Pandey et al., 2015). In quail manure, a factor of 3.5 higher of this element was observed in relation to other manures. Research show that increased soil phosphorus has affected the growth of medicinal plants, such as Calendula officinalis (Moreira et al., 2005), Pfafia glomerata (Serra et al., 2011), Pimpinella anisum, Coriandrum sativum, and Foeniculum vulgare (Khalid, 2012). Another element that was superior in quail manure was potassium, being three times higher in relation to cattle and seven in relation to the organic compost. Potassium is one of the few cations that are not present in organic structures. It is highly involved in osmotic regulation, maintenance of electrochemical balance in cells and their compartments, and regulation of enzymatic activity (Pinto \& Ferreira, 2015). Calcium, magnesium, and sulfur also had higher levels in quail manure. Calcium plays an important role in morphogenesis and exerts structural function, since it acts in the wall formation and in cellular division processes (Arruda et al., 2000). Magnesium is considered the major activator of enzymes, especially those associated with energy metabolism of plants (Paula et al., 2015) and is the central atom of the chlorophyll molecule (Shaul, 2002). Sulfur has the role of being an active group of enzymes and coenzymes, besides being a component of coenzymes (Malavolta et al., 1997).

It was observed that the plants of $C$. flexuosus had higher levels of macro and micronutrients when grown on substrate with quail manure compared to cattle manure and organic compost (Table 2). According to Malavolta et al. (1997), the nitrogen sufficiency range for Poaceae varies from 1.2 to $1.5 \%$. The results from this study were observed values between 1.52 and $1.79 \%$ in plants fertilized with quail manure, thus indicating a good supply. For the phosphorus, except for the control, all the treatments obtained values superior to the sufficiency range. 
Malavolta et al. (1997) also suggested that the potassium content varies between 1.1 and $1.5 \%$ and only the quail manure provided levels within the adequate sufficiency range. For magnesium, the range from 0.1 to $0.2 \%$ was verified for the doses of 450 and $600 \mathrm{~g} \mathrm{pot}^{-1}$ of cattle manure and all doses of manure quail. Regarding calcium and sulfur, all the treatments obtained values within the suggested limit.

Table 2. Leaf analysis of macronutrients and micronutrients of C. flexuosus with different sources of manures (cattle and quail) and compost, and doses $\left(150,300,450\right.$, and $\left.600 \mathrm{~g} \mathrm{pot}^{-1}\right)$ in the $1^{\text {st }}$ and $2^{\text {nd }}$ cut $(\mathrm{Ct})$

\begin{tabular}{|c|c|c|c|c|c|c|c|c|c|c|c|c|c|}
\hline \multicolumn{2}{|c|}{ Sources and doses $\left(\mathrm{g} \mathrm{pot}^{-1}\right)$} & $\mathrm{Ct}$ & $\mathrm{N}$ & $P$ & $\mathrm{~K}$ & $\mathrm{Ca}$ & $\mathrm{Mg}$ & $\mathrm{S}$ & B & $\mathrm{Cu}$ & $\mathrm{Mn}$ & $\mathrm{Zn}$ & $\mathrm{Fe}$ \\
\hline & & & \multicolumn{6}{|c|}{ 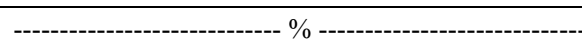 } & \multicolumn{5}{|c|}{ 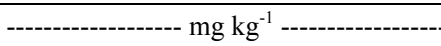 } \\
\hline & \multirow{2}{*}{0} & $1 \mathrm{st}$ & 1.1 & 0.1 & 1.0 & 0.4 & 0.1 & 0.1 & 23 & 5 & 23 & 13 & 345 \\
\hline & & 2nd & 1.1 & 0.1 & 0.9 & 0.4 & 0.1 & 0.1 & 13 & 2 & 25 & 9 & 334 \\
\hline \multirow{8}{*}{ 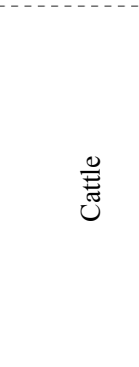 } & \multirow{2}{*}{150} & $1 \mathrm{st}$ & 1.1 & 0.1 & 1.0 & 0.4 & 0.1 & 0.1 & 23 & 4 & 27 & 14 & 276 \\
\hline & & 2 nd & 0.9 & 0.2 & 0.7 & 0.4 & 0.1 & 0.1 & 13 & 1 & 27 & 6 & 316 \\
\hline & \multirow{2}{*}{300} & $1 \mathrm{st}$ & 1.1 & 0.2 & 1.0 & 0.4 & 0.1 & 0.1 & 25 & 4 & 22 & 13 & 301 \\
\hline & & 2 nd & 0.9 & 0.2 & 0.8 & 0.5 & 0.1 & 0.1 & 10 & - & 28 & 7 & 222 \\
\hline & \multirow{2}{*}{450} & $1 \mathrm{st}$ & 1.1 & 0.2 & 0.9 & 0.5 & 0.1 & 0.1 & 24 & 4 & 33 & 14 & 406 \\
\hline & & 2 nd & 0.9 & 0.3 & 0.8 & 0.4 & 0.1 & 0.1 & 13 & 1 & 26 & 10 & 193 \\
\hline & \multirow{2}{*}{600} & $1 \mathrm{st}$ & 1.1 & 0.2 & 0.7 & 0.5 & 0.1 & 0.1 & 26 & 4 & 36 & 14 & 420 \\
\hline & & 2 nd & 0.8 & 0.3 & 0.8 & 0.4 & 0.1 & 0.1 & 19 & 1 & 30 & 9 & 176 \\
\hline \multirow{8}{*}{$\overline{\tilde{\Xi}}$} & \multirow{2}{*}{150} & $1 \mathrm{st}$ & 1.5 & 0.2 & 1.1 & 0.5 & 0.1 & 0.1 & 27 & 6 & 41 & 25 & 300 \\
\hline & & 2 nd & 1.5 & 0.2 & 1.1 & 0.3 & 0.1 & 0.2 & 18 & 4 & 43 & 20 & 167 \\
\hline & \multirow{2}{*}{300} & $1 \mathrm{st}$ & 1.7 & 0.2 & 1.2 & 0.6 & 0.1 & 0.2 & 31 & 8 & 51 & 33 & 297 \\
\hline & & 2 nd & 1.7 & 0.2 & 1.4 & 0.4 & 0.1 & 0.2 & 36 & 5 & 29 & 24 & 103 \\
\hline & \multirow{2}{*}{450} & $1 \mathrm{st}$ & 1.7 & 0.1 & 1.3 & 0.4 & 0.1 & 0.2 & 29 & 6 & 32 & 25 & 291 \\
\hline & & 2 nd & 1.8 & 0.2 & 1.3 & 0.3 & 0.1 & 0.2 & 62 & 5 & 31 & 21 & 124 \\
\hline & \multirow{2}{*}{600} & $1 \mathrm{st}$ & 1.6 & 0.2 & 1.3 & 0.4 & 0.1 & 0.1 & 27 & 6 & 37 & 25 & 310 \\
\hline & & $2 \mathrm{nd}$ & 1.7 & 0.2 & 1.3 & 0.3 & 0.2 & 0.2 & 43 & 4 & 26 & 20 & 123 \\
\hline \multirow{8}{*}{ 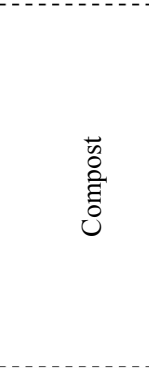 } & \multirow{2}{*}{150} & $1 \mathrm{st}$ & 1.0 & 0.1 & 0.7 & 0.4 & 0.1 & 0.1 & 24 & 3 & 27 & 11 & 634 \\
\hline & & 2 nd & 0.8 & 0.3 & 1.1 & 0.5 & 0.1 & 0.1 & 41 & 1 & 27 & 9 & 204 \\
\hline & \multirow{2}{*}{300} & $1 \mathrm{st}$ & 1.1 & 0.2 & 1.0 & 0.5 & 0.1 & 0.1 & 25 & 4 & 31 & 15 & 434 \\
\hline & & 2 nd & 0.9 & 0.3 & 1.0 & 0.5 & 0.1 & 0.1 & 44 & 1 & 30 & 11 & 192 \\
\hline & \multirow{2}{*}{450} & $1 \mathrm{st}$ & 1.2 & 0.2 & 0.9 & 0.5 & 0.1 & 0.1 & 23 & 4 & 27 & 18 & 570 \\
\hline & & $2 \mathrm{nd}$ & 0.9 & 0.4 & 1.0 & 0.4 & 0.1 & 0.1 & 62 & 2 & 23 & 15 & 200 \\
\hline & \multirow{2}{*}{600} & $1 \mathrm{st}$ & 1.4 & 0.3 & 0.8 & 0.5 & 0.1 & 0.1 & 26 & 6 & 38 & 23 & 796 \\
\hline & & 2 nd & 0.9 & 0.4 & 1.3 & 0.5 & 0.1 & 0.1 & 44 & 2 & 29 & 27 & 242 \\
\hline \multirow{2}{*}{ 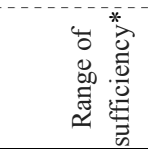 } & \multicolumn{2}{|l|}{ Low } & 1.2 & 0.08 & 1.1 & 0.3 & 0.1 & 0.1 & 15 & 5 & 80 & 20 & 100 \\
\hline & \multicolumn{2}{|l|}{ High } & 1.5 & 0.12 & 1.5 & 0.6 & 0.2 & 0.2 & 30 & 15 & 300 & 50 & 200 \\
\hline
\end{tabular}

Note. * Malavolta, 1997.

Considering that the best doses of quail manure for the biomass yield was between 300 and $450 \mathrm{~g} \mathrm{pot}^{-1}$, the appropriate leaf macronutrient contents are from 1.7 to $1.8(\mathrm{~N}) ; 0.2(\mathrm{P}) ; 1.1(\mathrm{~K}) ; 0.5(\mathrm{Ca}) ; \mathrm{Mg}(0.1)$, and $0.1(\mathrm{~S})$ and of micronutrients from 27 to $31(\mathrm{~B}) ; 6$ to $8(\mathrm{Cu}) ; 41$ to $51(\mathrm{Mn}) ; 25$ to $33(\mathrm{Zn})$, and $300(\mathrm{Fe})$. Therefore, it is suggested that the nutrients that most differentiate the total dry weight gain were $\mathrm{N}$ and $\mathrm{Mn}$ in which contents from 1.5 to $1.7 \%$ of $\mathrm{N}$ and 41 to $51 \mathrm{mg} \mathrm{kg}^{-1}$ of $\mathrm{Mn}$ are related to higher dry weights.

The interaction among sources and doses of manures and compost was not significant for the essential oil contents of $C$. flexuosus; therefore, the simple effects of factors (source and doses) were studied. On other hand, significant interaction was observed for essential oil yield (Table 3). Quail manure provided the highest levels of essential oil in the $1^{\text {st }}(1.71 \%)$ and in the $2^{\text {nd }}(1.93 \%)$ cuts (Table 3$)$. It was also observed that the content of the $2^{\text {nd }}$ cut was higher compared to the $1^{\text {st }}$ cut using quail manure and organic compost. Regarding the doses, it was verified that the supplementation with manures positively influence the essential oil content, and the lowest 
content occurred without fertilization. In absolute values, the highest average content in the $1^{\text {st }}(1.73 \%)$ and in the $2^{\text {nd }}(1.92 \%)$ cut was obtained with $300 \mathrm{~g} \mathrm{pot}^{-1}$ of treatments (Table 3$)$. These results corroborate with those by Correa et al. (2010), which verified higher essential oil content of Origanum vulgare with higher doses of manures. However, Silva et al. (2007) evaluated the effect of the absence of fertilization on the essential oil yield of Baccharis trimera and verified that the oil content tended to increase when fertilization was not used.

Table 3. Effect of source and doses of organic manures on the contents of the $1^{\text {st }}$ and $2^{\text {nd }}$ cuts and total essential oil yield of C. flexuosos

\begin{tabular}{|c|c|c|c|c|}
\hline Source & Doses $\left(\mathrm{g} \mathrm{plot}^{-1}\right)$ & $1^{\text {st }}$ Content (\%) & $2^{\text {nd }}$ Content $(\%)$ & Yield $\left(\mathrm{g} \mathrm{plan}^{\mathrm{t}-1}\right)$ \\
\hline \multirow[t]{5}{*}{ Cattle } & 0 & 1.50 & 1.44 & $20.09 \mathrm{~g}$ \\
\hline & 150 & 1.69 & 1.43 & 33.67 ef \\
\hline & 300 & 1.70 & 1.68 & $45.41 \mathrm{de}$ \\
\hline & 450 & 1.64 & 1.41 & $44.66 \mathrm{de}$ \\
\hline & 600 & 1.47 & 1.91 & $47.26 \mathrm{~d}$ \\
\hline \multirow[t]{5}{*}{ Quail } & 0 & 1.50 & 1.44 & $20.09 \mathrm{~g}$ \\
\hline & 150 & 1.64 & 1.93 & $98.50 \mathrm{a}$ \\
\hline & 300 & 1.80 & 2.26 & $103.96 \mathrm{a}$ \\
\hline & 450 & 1.83 & 2.18 & $84.07 \mathrm{~b}$ \\
\hline & 600 & 1.79 & 1.85 & $84.74 \mathrm{~b}$ \\
\hline \multirow[t]{5}{*}{ Compost } & 0 & 1.50 & 1.44 & $20.09 \mathrm{~g}$ \\
\hline & 150 & 1.56 & 1.70 & $27.41 \mathrm{fg}$ \\
\hline & 300 & 1.68 & 1.83 & $53.47 \mathrm{~cd}$ \\
\hline & 450 & 1.62 & 1.83 & $51.28 \mathrm{~cd}$ \\
\hline & 600 & 1.56 & 1.73 & $61.66 \mathrm{c}$ \\
\hline \multicolumn{5}{|l|}{ Means for source } \\
\hline Cattle & & $1.60 \mathrm{~b}^{\mathrm{a}}$ & $1.57 \mathrm{~b}$ & $38.22 \mathrm{~b}$ \\
\hline Quail & & $1.71 \mathrm{a}$ & $1.93 \mathrm{a}$ & $78.27 \mathrm{a}$ \\
\hline Compost & & $1.59 \mathrm{~b}$ & $1.71 \mathrm{~b}$ & $42.78 \mathrm{~b}$ \\
\hline \multicolumn{5}{|c|}{ Means for doses $\left(g\right.$ plot $\left.^{-1}\right)$} \\
\hline 0 & & $1.50 \mathrm{c}$ & $1.44 \mathrm{~b}$ & $20.09 \mathrm{~d}$ \\
\hline 150 & & $1.63 \mathrm{ab}$ & $1.69 \mathrm{a}$ & $53.20 \mathrm{c}$ \\
\hline 300 & & $1.73 \mathrm{a}$ & $1.92 \mathrm{a}$ & $67.61 \mathrm{a}$ \\
\hline 450 & & $1.70 \mathrm{ab}$ & $1.81 \mathrm{a}$ & $60.00 \mathrm{bc}$ \\
\hline 600 & & $1.61 \mathrm{bc}$ & $1.83 \mathrm{a}$ & $64.55 \mathrm{ab}$ \\
\hline \multicolumn{5}{|c|}{ Source of variation } \\
\hline Source $\times$ Doses & & n.s. & n.s. & $* * *$ \\
\hline Source & & $* *$ & $* * *$ & $* * *$ \\
\hline Doses & & $* * *$ & $* *$ & $* * *$ \\
\hline
\end{tabular}

Note. Significant effect: $* p \leq 0.05 ; * * p \leq 0.01 ; * * p \leq 0.001 ;$ n.s.: not significant.

${ }^{a}$ Mean within a column followed by the same letter are not significantly different according to Duncan's multiple range test at $p \leq 0.05$.

Regarding the essential oil yield of $C$. flexuosus, the quail manure at all tested dosages provided the highest averages compared to cattle manure and compost (Table 3 ). The highest range of essential oil yields (99.77 to $108.15 \mathrm{~g} \mathrm{plant}^{-1}$ ) was verified at the dose of $300 \mathrm{~g} \mathrm{pot}^{-1}$ of quail manure. Equal and superior doses of $300 \mathrm{~g} \mathrm{pot}^{-1}$ resulted in higher essential oil yield for cattle manure and compost, being statistically similar. As already discussed, C. flexuosus responded positively to the increase of soil nutrients both in terms of growing and production of secondary metabolites. The essential oil yield extracted from the leaves increased with the use of quail manure due to the direct relationship with the plant biomass yield. This same correlation was observed by Sales et al. (2009) in Hyptis marrubioides, Rosal et al. (2011) in Plectranthus neochiliusand and Corrêa et al. (2010) in Origanum vulgare. According to Rosal et al. (2011), there is no consensus in the literature regarding 
the response of essential oil yield to the use of different fertilizers and doses. This may be related to the fact that medicinal plants comprise a wide and diversified group of species, with great variability in the production of secondary metabolites, whose biosynthesis varies according to extrinsic and intrinsic factors to the species.

The chemical analysis of the essential oil of $C$. flexuosus resulted in the identification of 16 compounds, from which 14 are monoterpenes. Linalool, neral, geraniol, geranial, neryl acetate, and geranyl acetate together corresponded to $80 \%$ of the relative area of the peaks. The oil consisted mainly ( 75 to $85 \%$ ) of a monoterpene aldehyde termed citral (3,7-dimethyl-2,6-octadienal) which is a racemic mixture of the geranial and neral isomers (Gupta \& Ganjewala, 2015). The main therapeutic and biological activities are attributed to this monoterpene (Ganjewala \& Luthra, 2010; Vera et al., 2014; Adukwu et al., 2016). In our research, it was observed that the average content of neral (24.08\%) and geranial (48.81\%) contributed with more than $72 \%$. Silva et al. (2015) also identified these constituents as the main ones in the analysis of the oil of C. flexuosus, being the $33.40 \%$ of neral and $46.86 \%$ of geranial, and Adukwu et al. (2016) found $89 \%$ of citral in the oil, being $38.5 \%$ of neral and $50.5 \%$ of geranial.

It was observed a fitting of $87.21 \%(\mathrm{PC} 1+\mathrm{PC} 2)$ by the principal component analysis (PCA) of the six major chemical compounds. PCs separated these treatments within two groups: (control + quail) and (cattle + compost) Control treatment and quail manure at all dosages were differentiated from cattle manure and compost (Figure 2). It was possible to verify that cattle manure and compost showed higher content of neryl acetate and geranial, regardless of the dose. On the other hand, the control positively influenced the geraniol content, whereas the quail manure influenced the contents of neral, linalool, and geranyl acetate (Figure 2). Based on this multivariate analysis, it can also suggest that geranial and neryl acetate showed negative correlation with linalool, geranyl acetate, and geraniol, respectively. Ganjewala and Luthra (2010) studied the biosynthetic route of C. flexuosus and concluded that geraniol is subjected to oxidation by a geraniol dehydrogenase enzyme in order to produce geranial, which is converted to neral through an isomerase.

Cost-benefit analysis did not perform in this research. However, it is possible to demonstrate relevant aspects about results obtained. Quail manure provided better growth (300 to $\left.450 \mathrm{~g} \mathrm{pot}^{-1}\right)$ and essential oil yield (150 to $\left.300 \mathrm{~g} \mathrm{pot}^{-1}\right)$ in lower amount in relation other manures $\left(600 \mathrm{~g} \mathrm{pot}^{-1}\right)$. Normally, manures are collected on farms located near area cultivation by low cost and the largest part of costs of manures is related to their transportation. So, we believe the best economic benefit of quail manure in this study is justified. The costs between conventional and organic systems depend of several factors based on the type of crops, localization (regions), and technologies used in the studies. But, the cultivation with manures can be beneficial due less use of chemical inputs, diminish soil erosion, water conservation, and meliorated soil and biodiversity (Pimentel et al., 2005).

Cattle, quail, and compost at different doses altered the dry weight gain, content, yield and chemical composition of the essential oil of Cymbopogon flexuosus. The species increased the growth and productions of secondary metabolites by use the manures and organic compost. The highest biomass yield was obtained with fertilization between 300 and $450 \mathrm{~g} \mathrm{pot}^{-1}$ of quail manure, but the yield of essential oil in the doses from 150 to $300 \mathrm{~g} \mathrm{pot}^{-1}$. The neral content in the essential oil was increased with the use of $450 \mathrm{~g} \mathrm{pot}^{-1}$ of quail manure compared to compost and cattle manure. 

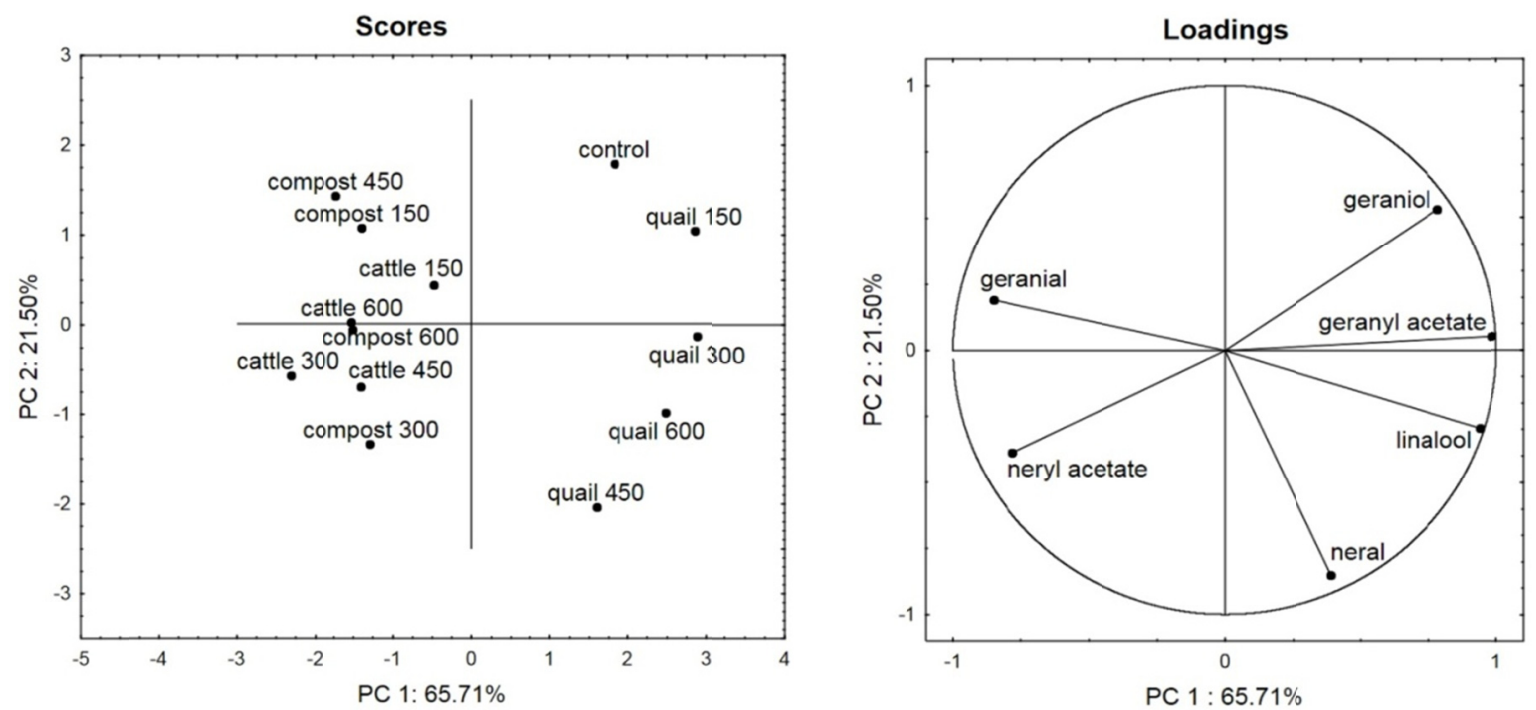

Figure 2. Principal component analysis (PCA) of the averages of major compounds of the essential oil of $C$. flexuosus in different sources and doses of manures and compost

\section{Acknowledgements}

This study was financed in parts by National Council for Scientific and Technological Development (CNPq - Conselho Nacional de Desenvolvimento Científico e Tecnológico), the Minas Gerais State Research Foundation (FAPEMIG-Fundação de Pesquisa do Estado de Minas Gerais), and the Coordination for the Improvement of Higher Education Personnel (CAPES - Coordenação de Aperfeiçoamento de Pessoal de Nível Superior - Brasil (CAPES-Finance Code 001).

\section{References}

Adams, R. P. (2007). Identification of essential oils by ion trap mass spectroscopy. Academic Press.

Adukwu, E. C. Bowles, M. Edwards-Jones, V., \& Bone, H. (2016). Antimicrobial activity, cytotoxicity and chemical analysis of lemongrass essential oil (Cymbopogon flexuosus) and pure citral. Appl Microbiol Biotechnol, 100, 9619-9627. https://doi.org/10.1007/s00253-016-7807-y

Arruda, S., Souza, G., Almeida, M., \& Gonçalves, A. (2000). Anatomical and biochemical characterization of the calcium effect on Eucalyptus urophylla callus morphogenesis in vitro. Plant Cell, Tissue and Organ Culture 63, 142-154. https://doi.org/10.1023/A:1006482702094

Bezerra, A. M. E., Júnior, F. T. d. N., Leal, F. R., \& Carneiro, J. G. d. M. (2006). Rendimento de biomassa, óleo essencial, teores de fósforo e potássiode chambá em resposta à adubação orgânica e mineral. Revista Ciência Agronômica, 37, 124-129.

Brant, R. D. S., Pinto, J. E. B., Bertolucci, S. K., \& Albuquerque, C. J. B. (2010). Produção de biomassa e teor do óleo essencial de cidrão em função da adubação orgânica. Horticultura Brasileira, 28, 111-114. https://doi.org/10.1590/S0102-05362010000100021

Bufalo, J., Cantrell, C. L., Astatkie, T., Zheljazkov, V. D., Gawde, A., \& Boaro, C. S. F. (2015). Organic versus conventional fertilization effects on sweet basil (Ocimum basilicum L.) growth in a greenhouse system. Industrial Crops and Products, 74, 249-254. https://doi.org/10.1016/j.indcrop.2015.04.032

Chagas, J. H., Pinto, J. E. B., Bertolucci, S. K., Santos, F. M., Botrel, P. P., \& Pinto, L. B. (2011). Produção da hortelã-japonesa em função da adubação orgânica no plantio e em cobertura. Horticultura Brasileira, 29, 412-417. https://doi.org/10.1590/S0102-05362011000300026

Corrêa, R. M., Pinto, J. E. B. P., Reis, E. S., Costa, L. C. B., Alves, P. B., Niculan, E. S., \& Brant, R. S. (2010). Adubação orgânica na produção de biomassa de plantas, teor e qualidade de óleo essencial de orégano (Origanum vulgare L.) em cultivo protegido. Revista Brasileira de Plantas Medicinais, 12, 80-89. https://doi.org/10.1590/S1516-05722010000100012

Costa, L. C. D. B., Pinto, J. E. B. P., Castro, E. M. D., Bertolucci, S. K. V., Corrêa, R. M., Reis, É. S., ... Niculau, E. D. S. (2008). Tipos e doses de adubação orgânica no crescimento, no rendimento e na composição 
química do óleo essencial de elixir paregórico. Ciência Rural, 38, 2173-2180. https://doi.org/10.1590/ S0103-84782008000800013

Davies, N. W. (1990). Gas chromatographic retention indices of monoterpenes and sesquiterpenes on methyl silicon and Carbowax 20M phases. Journal of Chromatography A, 503, 1-24. https://doi.org/10.1016/ S0021-9673(01)81487-4

EMBRAPA. (1997). Manual de métodos de análise de solo. Rio de Janeiro: Embrapa Solos.

Ganjewala, D., \& Luthra, R. (2010). Essential oil biosynthesis and regulation in the genus Cymbopogon. Nat Prod Commun, 5, 163-172.

Garlet, T. M. B., \& Santos, O. S. d. (2008). Solução nutritiva e composição mineral de três espécies de menta cultivadas no sistema hidropônico. Ciência Rural, 38, 1233-1239. https://doi.org/10.1590/S0103-84 782008000500005

Gupta, A. K., \& Ganjewala, D. (2015). A study on biosynthesis of "citral" in lemongrass (C. flexuosus) cv. Suvarna. Acta Physiologiae Plantarum, 37. https://doi.org/10.1007/s11738-015-1989-2

Khalid, K. A. (2012). Effect of NP and foliar spray on growth and chemical compositions of some medicinal Apiaceae plants grow in arid regions in Egypt. Journal of Soil Science and Plant Nutrition, 12, 581-596. https://doi.org/10.4067/S0718-95162012005000018

Maia, S. S. S., Pinto, J. E. B. P., Silva, F. N., \& Oliveira, C. (2008). Influência da adubação orgânica e mineral no cultivo do bamburral (Hyptis suaveolens (L.) Poit.) (Lamiaceae). Revista Brasileira de Ciências Agrárias, 3, 327-331. https://doi.org/10.5039/agraria.v3i4a331

Malavolta, E., Vitti, G. C., \& Oliveira, S. A. D. (1997). Avaliação do estado nutricional das plantas: Princípios e aplicações.

Marigowda, V. J, H. M. A., Mn, S., \& Saraswathi, T. (2016). Studies on antibacterial, antioxidant and anticancerous activity using essential oil from Cymbopogon flexuosus (stapf). International Journal of Advanced Research, 4, 1324-1341. https://doi.org/10.21474/IJAR01/2526

Marques, C. T. D. S., Gama, E. V. S., da Silva, F., Teles, S., Caiafa, A. N., \& Lucchese, A. M. (2018). Improvement of biomass and essential oil production of Lippia alba (Mill) N.E. Brown with green manures in succession. Industrial Crops and Products, 112, 113-118. https://doi.org/10.1016/j.indcrop.2017.10.065

Marschner, H. (2012). Marschner's mineral nutrition of higher plants. Academic Press.

May, A., Bovi, O. A., Maia, N. B., Moraes, A. R. D., Pinheiro, M. Q., \& Mario, M. D. (2008). Influência do intervalo entre cortes sobre a produção de biomassa de duas espécies de capim limão. Horticultura Brasileira, 26, 379-382. https://doi.org/10.1590/S0102-05362008000300017

Meena, S., Kumar, S. R., Venkata Rao, D. K., Dwivedi, V., Shilpashree, H. B., Rastogi, S., ... Nagegowda, D. A. (2016). De Novo Sequencing and Analysis of Lemongrass Transcriptome Provide First Insights into the Essential Oil Biosynthesis of Aromatic Grasses. Front Plant Sci, 7, 1129. https://doi.org/10.3389/fpls.201 6.01129

Moreira, P. A., Marchetti, M. E., Vieira, M. C., Novelino, J. O., Gonçalves, M. C., \& Robaina, A. D. (2005). Desenvolvimento vegetativo e teor foliar de macronutrientes da calêndula (Calendula officinalis L.) adubada com nitrogênio e fósforo. Revista Brasileira de Plantas Medicinais, 8.

NIST. (2008). PC version 2.0 of the NIST/EPA/NIH Mass Spectral Library. Gaithersburg: U.S.

Pandey, R., Zinta, G., AbdElgawad, H., Ahmad, A., Jain, V., \& Janssens, I. A. (2015). Physiological and molecular alterations in plants exposed to high $\left[\mathrm{CO}_{2}\right]$ under phosphorus stress. Biotechnology Advances, 33, 303-316. https://doi.org/10.1016/j.biotechadv.2015.03.011

Paula, Y. C. M., Pasqual, M., Pio, L. A. S., Pinho, P. J. D., \& Santos, D. N. D. (2015). Micropropagação de bananeira sob diferentes concentrações de potássio e magnésio. Tecnologia \& Ciencia Agropecuária, 9, 43-47.

Pimentel, D., Hepperly, P., Hanson, J., Douds, D., \& Seidel, R. (2005). Environmental, Energetic, and Economic Comparisons of Organic and Conventional Farming Systems. BioScience, 55(7), 573-582. https://doi.org/ 10.1641/0006-3568(2005)055[0573:EEAECO]2.0.CO;2

Pinto, E., \& Ferreira, I. (2015). Cation transporters/channels in plants: Tools for nutrient biofortification. Journal of Plant Physiology, 179, 64-82. https://doi.org/10.1016/j.jplph.2015.02.010 
Rosal, L. F., Pinto, J. E. B. P., Bertolucci, S. K. V., Brant, R. D. S., Niculau, E. D. S., \& Alves, P. B. (2011). Produção vegetal e de óleo essencial de boldo pequeno em função de fontes de adubos orgânicos. Revista Ceres, 58, 670-678. https://doi.org/10.1590/S0034-737X2011000500020

Sales, J. F., Pinto, J. E. B. P., Botrel, P. P., Silva, F. G., Correa, R. M., \& Carvalho, J. G. D. (2009). Acúmulo de massa, teor foliar de nutrientes e rendimento de óleo essencial de hortelã-do-campo (Hyptis marrubioides Epl.) cultivado sob adubação orgânica. Bioscience Journal, 25, 60-68.

Serra, A. P., Marchetti, M. E., Vieira, M. C., Silva, M. A. G., Rosa Junior, E. J., Nascimento, J. M., \& Guedes, E. M. S. (2011). Produção de biomassa e absorção de N e P pela Pfaffia glomerata (Spreng.) Pedersen em função de doses de N e P em condições de casa de vegetação. Revista Brasileira de Plantas Medicinais, 13, 265-270. https://doi.org/10.1590/S1516-05722011000300003

Sharma, P. R., Mondhe, D. M., Muthiah, S., Pal, H. C., Shahi, A. K., Saxena, A. K., \& Qazi, G. N. (2009). Anticancer activity of an essential oil from Cymbopogon flexuosus. Chem Biol Interact, 179, 160-168. https://doi.org/10.1016/j.cbi.2008.12.004

Shaul, O. (2002). Magnesium transport and function in plants: The tip of the iceberg. Biometals, 15, 307-321. https://doi.org/10.1023/A:1016091118585

Silva, F. C. D. (2009). Manual de análises químicas de solos, plantas e fertilizantes. Embrapa Informação Tecnológica; Rio de Janeiro: Embrapa Solos Brasília.

Silva, F. G., Pinto, J. E. B. P., Cardoso, M. G., Sales, J. F., Mol, D. J. S., \& Divino, S. P. (2007). Influence of manure and fertilizer on Baccharis trimera (Less.) D.C. growth and essential oil yield. Journal of Herbs, Spices \& Medicinal Plants, 13, 83-92. https://doi.org/10.1300/J044v13n01_07

Silva, J. S. P., Alves, E. P., Bertolucci, S. F., M. Andrade, C., \& Resende, M. (2015). Essential oil of Cymbopogon flexuosus, Vernonia polyanthes and potassium phosphite in control of bean anthracnose. Ebène. Journal of Medicinal Plants Research, 9, 243-253. https://doi.org/10.5897/JMPR2014.5718

Silva, S. P. D., Viégas, I. D. J. M., Okumura, R. S., Silva, D. A. S., Galvão, J. R., Júnior, M. L. D. S., ... Silva, A. O. D. (2018). Growth and micronutrients contents of smell pepper (Capsicum chinense Jac.) submitted to organic fertilizer. Journal of Agricultural Science, 10, 425-435. https://doi.org/10.5539/jas.v10n11p425

Van den Dool, H., \& Kratz, P. D. (1963). A generalization of the retention index system including linear temperature programmed gas-liquid partition chromatography. Journal of Chromatography A, 11, 463-471. https://doi.org/10.1016/S0021-9673(01)80947-X

Vera, S. S., Zambrano, D. F., Mendez-Sanchez, S. C., Rodriguez-Sanabria, F., Stashenko, E. E., \& Duque Luna, J. E. (2014). Essential oils with insecticidal activity against larvae of Aedes aegypti (Diptera: Culicidae). Parasitol Res, 113, 2647-2654. https://doi.org/10.1007/s00436-014-3917-6

\section{Copyrights}

Copyright for this article is retained by the author(s), with first publication rights granted to the journal.

This is an open-access article distributed under the terms and conditions of the Creative Commons Attribution license (http://creativecommons.org/licenses/by/4.0/). 